Florea : Jurnal Biologi dan Pembelajarannya, 8(1), 2021, 48-51

This is an open access article under the CC-BY-SA license (https://creativecommons.org/licenses/by-sa/4.o/)

ISSN 2355-6102(print), ISSN 2502-0404(online)

DOI : $10.25273 /$ florea.v8i1.8071

\title{
ANALISIS FAKTOR TERJADINYA PERUBAHAN EKOSISTEM SAWAH
}

\author{
Ana Alimatul Himmah ${ }^{1)}$ Siti Zahrotul Choiriyah ${ }^{2)}$ Alfiatur Rohmah ${ }^{3)}$ Achmad Ali Fikri ${ }^{4)}$ \\ 1)2)3)4) Program Studi Tadris Biologi IAIN Kudus \\ email: anahimmah55@gmail.com
}

Diterima 2 Februari 2021 disetujui 13 April 2021 diterbitkan 15 Mei 2021

\begin{abstract}
This study aims to determine the factors of changes in the rice field ecosystem. The method used in this research is descriptive qualitative. Data collection techniques by observation, interviews and supported by literature study from relevant reference sources. Based on the results of observations, interviews and literature studies that have been conducted, three factors have been found to change the rice field ecosystem. Starting from the most influential factors, namely the use of fertilizers and chemicals, genetic engineering, and land narrowing. With this, the authors hope to provide information to the community about changes in the ecosystem caused by their own exploitation of agricultural land.
\end{abstract}

Keyword: factors, changes in the ecosystem, rice fields.

\section{PENDAHULUAN}

Lahan pertanian semakin berkurang, hal tersebut dapat disebabkan oleh beberapa faktor, diantaranya yaitu digunakan sebagai lahan permukiman dan lahan industri. Lahan merupakan sumber daya alam yang memiliki fungsi yang sangat penting bagi pembangunan suatu Negara. Proses pembangunan, hampir semua sektor memerlukan lahan seperti sektor pertanian, sektor industri, sektor perdagangan dan sektor infrastruktur. Sektor pertanian, lahan merupakan sumber daya penting, baik bagi petani maupun bagi pembangunan pertaniaan, hal ini berdasarkan pada kenyataan bahwasannya di Indonesia sebagai Negara agraris semua kegiatan pertanian masih bertumpu pada lahan karena lahan berperan sangat penting dalam

kegiatan produksi yang mampu menghasilkan kebutuhan pangan yang dibutuhkan oleh setiap manusia.

Pentingnya lahan bagi berbagai sektor membuat permintaan akan kegunaan lahan semakin meningkat, ini sesuai dengan

semakin meningkatnya pertambahan penduduk, namun ketersediaan lahan sangat terbatas, karena lahan merupakan factor terpenting yang tidak bisa diproduksi lagi oleh manusia atau sering disebut non produced input (Mubyarto, 1996:89).

Lahan pertanian di Jawa Tengah sendiri terjadi penurunan jumlah yang cukup tinggi, pernyataan tersebut didukung dengan data dari kementrian pertanian dimana terjadi penurunan luas lahan pertanian di jawa tengah pada tahun 2014 hingga 2017 sebesar 14.896,60. Ha. Luas lahan yang semakin menyempit tidak hanya berdampak pada menurunnya produksi pangan nasional, namun hal tersebut juga berdampak pada perubahan ekosisitem sawah.

Perubahan yang terjadi pada ekosistem dapat berdampak buruk bagi

keberlangsungan hidup organisme-organisme yang ada di ekosistem sawah atau bisa dikatakan sebagai ketidakseimbangan ekosistem. Maka dari itu perlu diketahui mengenai faktor-faktor penyebab perubahan ekosistem agar tidak berdampak buruk pada keseimbangan ekosistem. Itulah yang membuat peneliti merasa tergugah untuk melakukan penelitian ini agar dapat dijadikan pengetahuan bagi para pelaku pertanian supaya dapat meminimalisir faktor-faktor yang ada. 
Florea : Jurnal Biologi dan Pembelajarannya, 8(1), 2021, 48-51

This is an open access article under the CC-BY-SA license (https://creativecommons.org/licenses/by-sa/4.0/)

ISSN 2355-6102(print), ISSN 2502-0404(online)

DOI : $10.25273 /$ florea.v8i1.8071

\section{METODE}

\section{Metode penelitian yang digunakan adalah deskriptif kualitatif.Teknik pengumpulan data yang digunakan adalah wawancara dan observasi dengan didukung oleh kajian pustaka terhadap sumber-sumber referensi yang relevan. \\ Subjek penelitian yang digunakan peneliti adalah Bapak Ali Mahfud, Bapak Darpan dan Bapak Yanto yang merupakan seorang petani sebagai narasumber yang dipilih oleh peneliti pada tanggal 02 Desember 2020.}

\section{HASIL DAN PEMBAHASAN Berdasarkan hasil penelitian dari peneliti ditemukan beberapa faktor penyebab dari perubahan ekosistem sawah, diantaranya:}

1. Penggunaan pupuk dan bahan kimia

Penggunaan pupuk dan pestisida di Indonesia mulai meningkat sejak gerakan revolusi hijau tahun 1970 an. Pada masa itu, penggunaan pupuk dan pestisida menjadi hal yang sangat penting bagi petani. Pupuk dan pestisida merupakan salah satu hal yang sangat dibutuhkan untuk sistem pertanian modern namun memiliki banyak dampak negatif. Penggunaan pupuk dan pestisida yang tidak sesuai dengan kebutuhan akan menyebabkan berbagai masalah baik untuk jangka pendek maupun jangka panjang.

petani untuk membasmi musuh tanaman. Dengan penggunaan pestisida akan meningkatkan hasil panen. Namun, penggunaan pestisida secara kontinu akan menimbulkan banyak dampak negatif, salah satunya kerusakan pada lahan pertanian.

Secara umum sifat pestisida merupakan pelindung manusia dari ancaman serangga, jamur, gulma, dan hewan pengganggu lainnya. Namun disisi lain, kandungan senyawa pestisida ternyata merupakan polutan bahkan racun bagi keselamatan ekosistem lingkungan, termasuk bagi tanah dan lingkungan hidup.

Pestisida dengan intensitas penggunaan yang terlalu tinggi dan dilakukan secara terus menerus akan berdampak pada beberapa kerugian antara lain pencemaran di lingkungan pertanian, penurunan produksifitas, keracunan pada hewan, bahkan keracunan pada manusia. Pestisida dapat menjadi penyebab kesuburan tanah menjadi berkurang dan juga dapat

mematikan fauna tanah sehingga menurunkan kesuburan tanah.

Hal tersebut merupakan realitas yang perlu dicermati bahwa tidak semua pestisida tepat mengenai sasaran. Hanya berkisar $20 \%$ saja yang tepat sasaran mengenai tanaman atau benar-benar efektif, sedangkan $80 \%$ justru terbuang jatuh ketanah. Jika tumpahan pestisida yang berlebihan pada permukaan tanah akan mencemari lingkungan tanah. Dampak negatif yang ditimbulkan oleh penggunaan pestisida secara belebihan dan terus-menerus yaitu berupa kerusakan pada lingkungan serta terjadinya ketidak seimbangan ekosisitem.

\section{Rekayasa genetika}

Rekayasa genetika merupakan salah satu cabang ilmu yang membahas mengenai modifikasi atau perubahan susunan genetik suatu organisme hidup untuk mengekspresikan sifat-sifat alami yang tidak diinginkan. Rekayasa genetika biasa digunakan manusia untuk merubah susunan genetika makhluk hidup agar sesuai dengan yang diperlukan.

Rekayasa genetika/modifikasi genetika sebenarnya sangat bermanfaat, yaitu dapat digunakan untuk menghasilkan varietas tanaman unggul dengan menggunakan bioteknologi. Varietas tanaman yang dihasilkan dapat berupa tanaman yang tahan terhadap hama dan penyakit.

Selain bermanfaat, rekayasa genetika juga memiliki dampak negatif bagi 
Florea : Jurnal Biologi dan Pembelajarannya, 8(1), 2021, 48-51

This is an open access article under the CC-BY-SA license (https://creativecommons.org/licenses/by-sa/4.o/)

ISSN 2355-6102(print), ISSN 2502-0404(online)

DOI : $10.25273 /$ florea.v8i1.8071

ekosistem, yaitu terganggunya keseimbangan ekosistem karena adanya dominasi GMO atas spesies alami.

3. Penyempitan lahan

Manusia merupakan suatu organisme yang paling banyak mempengaruhi ekosistem di bumi dengan sengaja. Perubahan tersebut bertujuan untuk mencukupi segala kebutuhan hidupnya. Namun kebutuhan jangka pendek yang diinginkan sering sekali mengorbankan kebutuhan jangka panjangnya. Mengalih fungsikan lahan pertanian menjadi lahan non pertanian dapat terjadi karena manusia yang lebih mementingkan keuntung jangka pendeknya. Suatu sistem ekonomi yang didasarkan pasar telah gagal menghargai jasa ekosistem, sehingga lahan pertanian dihargai lebih rendah dari nilai yang seharusnya dapat diperoleh.

Alih fungsi lahan yang terjadi dari lahan pertanian menjadi lahan non pertanian dapat berdampak pada semakin berkurangnya daerah peresapan air, menyebabkan habitat organisme hilang dan memicu terjadinya kompetisi atau persaingan dalam ekosistem. Misalnya, ketika dua atau lebih jenis tanaman tumbuh bersamaan dalam suatu

habitat, maka akan mengakibatkan terjadinya interaksi. Karena, Mlmasingmasing tanaman seharusnya memiliki ruang yang cukup untuk memaksimalkan kerjasama antar tanaman dan meminimalkan terjadinya kompetisi antar tanaman (Mangla et al., 2011).

Kompetisi antar komponen merupakan sebuab persaingan yang terjadi antara komponen penyusun abiotik dan komponen penyusun biotik di dalam suatu ekosistem. Persaingan merupakan suatu tipe hubungan jenis yang dapat terjadi pada dua atau lebih individu organisme baik hewan maupun tumbuhan dalam suatu ekosistem. Persaingan ini dapat terjadi karena faktorfaktor komponen yang tidak tersedia dalam jumlah yang cukup di lingkungannya (Setiadi dkk, 1989).

Keseimbangan suatu kompetisi mempunyai permasalahan yang cukup kompleks dalam prosesnya. Kompetisi interspesifik bersifat lebih dominan terhadap salah satu spesies dari pada kompetisi intraspesifik. keseimbangan kompetisi dapat di lihat dari ukuran suatu tanaman yang menjadi inangnya. Perbedaan ukuran tanaman inang dapat menjadi pembeda antara interspesifik dan intraspesifik (Evans, 2013).

Berdasarkan hasil wawancara yang telah dilakukan peneliti kepada ketiga narasumber terhadap faktor yang paling berpengaruh pada perubahan ekosistem sawah, yaitu faktor dari pestisida yang terbuat dari bahan kimia sebagai faktor paling dominan karena dampak perubahan ekosistem yang paling dapat dirasakan perubahannya. Penggunaan pestisida dapat mengurangi bahkan menghilangkan kesuburan tanah. Sebagai contoh penggunaan obat sumo untuk mematikan rumput justru sekaligus dapat menyebabkan kondisi tanah menjadi tidak subur karena sifat dari obat tersebut panas.

Penggunaan pupuk kimia yang berkonsentrasi tinggi dan dengan dosis yang tinggi dalam kurun waktu yang panjang

menyebabkan terjadinya kemerosotan kesuburan tanah karena terjadi ketimpangan hara atau kekurangan hara lain, dan semakin merosotnya kandungan bahan organik tanah. Hingga menyebabkan perubahan ekosistem.

\section{SIMPULAN}

Dari penelitian yang telah dilakukan dapat disimpulkan bahwa terdapat tiga faktor perubahan ekosistem di sawah, yaitu penggunaan pupuk dan bahan kimia, rekayasa genetika dan penyempitan lahan. Sedangkan faktor perubahan ekosistem yang paling dominan di rasakan oleh petani yaitu akibat dari penggunaan pupuk dan bahan kimia. Sehingga peneliti berharap, penelitian 
Florea : Jurnal Biologi dan Pembelajarannya, 8(1), 2021, 48-51

This is an open access article under the CC-BY-SA license (https://creativecommons.org/licenses/by-sa/4.0/)

ISSN 2355-6102(print), ISSN 2502-0404(online)

DOI : $10.25273 /$ florea.v8i1.8071

ini dapat memberikan informasi kepada masyarakat akan adanya perubahan ekosistem yang disebabkan oleh mereka sendiri yang terlalu mengeksploitasi lahan pertanian.

\section{DAFTAR PUSTAKA}

Sugiyono. (2014). Metode Penelitian Pendidikan Pendekatan Kuantitatif, Kualitatif, dan R\&D. Bandung: PT Alfabeta.

Arifin Gozali, Imam. Dkk. 2014. Kompetisi Antar Komponen Penyusun dalam Ekosistem. Jember : Universitas Jember. https://www.academia.edu/12360498 /Kompetisi_Antar_Komponen_Peny usun_dalam_Ekosistem

Rosalia Putri, Zara. 2015. Analisis Penyebab Alih Fungsi Lahan Pertanian Ke Lahan Non Pertanian Kabupaten / Kota Di Provinsi Jawa Tengah 2003-2013. Purwokerto:Universitas Jendral Soedirman. https://media.neliti.com/media/public ations/266551-analisis-penyebabalih-fungsi-lahan-pert-d37c2ead.pdf

kementrian Pertanian Republik Indonesia. 2019. Statistik Data Lahan Pertanian Tahun 20013 - 2017. Jakarta : Kementrian Pertanian Republik Indonesia.

http://epublikasi.setjen.pertanian.go.i d/download/file/471-statistik-datalahan-pertanian-tahun-2013-2017

Kompas.com. 2020. Rekayasa Genetik:

Pengertian, Manfaat, dan Dampaknya.

https://www.kompas.com/skola/read/ 2020/01/02/100000069/rekayasagenetik-pengertian-manfaat-dandampaknya?page $=$ all

Wiryono. 2011. Alih Fungsi Lahan

Pertanian Pangan Ditinjau dari Aspek

Biologis. Bengkulu : Universitas

Bengkulu. https://www.researchgate.net/publicati on/336676680_Alih_fungsi_lahan_per tanian_pangan_ditinjau_dari_aspek_e kologis 